\title{
Career Stages and Attitudes to Skills Development Process in Poland
}

\author{
Alicja Grześkowiak \\ Wrocław University of Economics \\ alicja.grzeskowiak@ue.wroc.pl
}

\section{Doi:10.5901/mjss.2015.v6n2s5p37}

\section{Abstract}

There is an undeniable need for the continuous improvement of skills and competences in the era of the knowledge-based economy. The necessity of lifelong learning activities is included in the strategic European documents. The degree of achievement of the objectives in the field of adult education varies substantially among the countries of the European Union. The situation in Poland as compared to other countries is unfavorable. This paper deals with the subject of attitudes towards the skills development process of the Polish labor force. The analyses are carried out on the basis of the microdata provided by a Polish nationwide survey on human capital conducted in 2013. According to the Super's theory some career stages combined with age are considered: the exploration, the establishment and the maintenance. A hypothesis is verified that the educational patterns are different at various stages of the career development. As the dataset contains nominal, ordinal and interval variables, some specific statistical methods are applied to identify the associations.

Keywords: skills development; career stages; statistical analysis;

\section{Introduction}

The knowledge-based economy combined with rapid changes incline all members of the labour force to continuously improve skills and competences. Lifelong learning process is an important component of the European Union educational strategies. International comparisons show that in Poland there is a very low percentage of adults engaged in training (European Commission, 2011b). Recent researches concerning Poland (Czapiński \& Panek 2013; GUS, 2009; Grześkowiak 2013; Grześkowiak 2014; Grześkowiak 2015) indicate that there are various factors associated with the involvement in educational activities as gender, place of residence, age, income, health condition, labour status, level of education.

The main objective of this paper is to analyze the attitudes towards improving skills with regard to career stages. According to the Super's theory some career phases can be distinguished in relation to age (Super, 1980). In this study the following division adapted from the Super's theory is applied:

- exploration (18-24 years),

- establishment (25-44 years),

- maintenance (45-64 years).

The Super's partition includes more stages like growth and decline (Super, 1980) but they concern persons beyond productive age and therefore are not considered in this paper.

Chosen statistical methods are applied to examine whether there are relationships between the above-defined career stages and various aspects of improving skills: participation in three forms of education, perception of learning new things in the context of the age, the time and the expenditure spent on education.

\section{Data Characteristics and Analytical Techniques}

This research is conducted on the basis of microdata collected during a nationwide survey on human capital in Poland named Bilans kapitału ludzkiego 2013. The sample size of this survey is equal to 17600 individuals in productive age (i. e. 18-64 for men and 18-59 for women). As education plays an important role in human capital formation, the survey includes a choice of questions concerning the attitudes to skills development process. The variables taken into consideration in this study are presented in Table 1. 
Table 1. List of variables under consideration

\begin{tabular}{lc}
\hline Variable & Description \\
\hline Participation in formal education (last 12 months) & binary variable \\
Participation in non-formal education (last 12 months) & binary variable \\
Self-learning activities (last 12 months) & binary variable \\
Age as a barrier to lifelong learning activities & binary variable \\
Ability to continuously learn new things & ordinal variable \\
Number of years since the last participation in training & metric variable \\
Number of hours devoted to training (last 12 months) & metric variable \\
Total personal expenditure on training (last 12 months) & metric variable \\
\hline
\end{tabular}

Source: Own elaboration based on variables from the survey Bilans kapitału ludzkiego 2013

The variables represent various aspects of involvement in activities aiming at developing skills. Although the overall sample size is as mentioned above, no complete data are available for certain variables. In these cases the analyses are conducted on the basis of a smaller number of records (17 597 for Ability to continuously learn new things, 2417 for Total personal expenditure on training, 2432 for Number of hours devoted to training, 3741 for Number of years since the last participation in training).

The variables are measured on different scales and therefore various approaches in the analyses are indispensable.

The chi-square test is applied in order to examine associations between pairs of non-metric variables. Since the chi-square statistic depends on the sample size, its usefulness as a measure of association is non convenient, hence the contingency coefficient is used to assess the strength of a relationship as its values are normalized between zero (independence) and one (full association) (Everitt, 1992, pp. 56-57). A directional measure - Goodman and Kruskal Tau having proportional reduction error interpretation is also calculated (see Reynolds, 1984). The associations in three-way contingency tables are evaluated by log-linear modeling (see e. g. Christensen, 1997). Some visualization techniques are applied to illustrate the relationships among nonmetric variables: doubledecker plots and mosaic plots (see Friendly 2000; Hornik, Zeileis \& Meyer, 2006) implemented in R vcd (Meyer, Zeileis \& Hornik, 2014). and vcdExtra (Friendly et al. , 2015) packages. In the case of metric variables a preliminary assessment of the compliance with the normal distribution is carried out using quantile-quantile plots and the normality is verified by the Kolmogorov-Smirnov test. The lack of normality limits the possibility of the application of classical ANOVA. Hence, an alternative method of comparison of distributions is a non-parametric Kruskal-Wallis test considered also as the one-way analysis of variance by ranks (see e. g. Sheskin, 2003).

All analysis are performed either in R or SPSS programme.

\section{Career Stages and Participation in Various Forms of Continuous Education}

According to the classification of educational activities used in European policies there are four forms of learning (European Commission, 2006; European Commission 2011a):

- formal education, which takes place in educational institutions and is a part of the educational system of the country,

- non-formal education provided outside the educational system,

- informal learning, which is neither organized nor structured,

- random learning, which is unintentional.

The last one is not a subject of statistical observation (European Commission, 2006). The other forms are treated as intentional learning and statistical data may be available on this topic. The Polish survey on human capital covers these three forms of improving knowledge and skills with the informal learning reflected in the questions on self-learning.

Double-decker charts depicting the contingency tables for selected age intervals and forms of education are presented in Figure 1. 
Figure 1. Doubledecker plots showing relationships between the career stages and the participation in various forms of continuous education

formal education

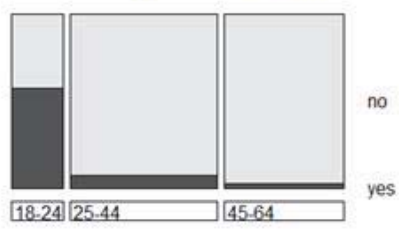

non-formal education

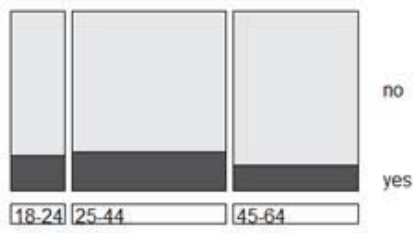

informal education

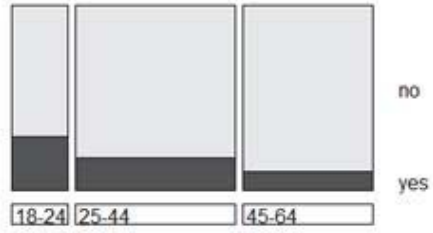

Source: Own elaboration in Rbased on data from Bilans kapitału ludzkiego 2013

The biggest differences can be observed in the case of formal education. Participation in the group at the beginning of professional career is much higher than in the others. The tendency towards developing skills through self-education decreases with age.

In order to check whether there are dependencies between the phases of professional development and the participation in various forms of education chi-square test as well as contingency and Goodman and Kruskal Tau coefficients are applied (Table 2).

Table 2. Measures of association between the career stages and the participation in various forms of continuous education

\begin{tabular}{lcccc}
\hline Type & Chi-square statistic & p-value & Contingency coefficient & Goodman Kruskal Tau \\
\hline Formal education & 5585,122 & 0,000 & 0,491 & 0,317 \\
Non-formal education & 119,665 & 0,000 & 0,082 & 0,007 \\
Informal education & 533,317 & 0,000 & 0,175 & 0,031 \\
\hline
\end{tabular}

Source: Own computations based on data from Bilans kapitału ludzkiego 2013

Chi-square test indicates that there are significant relationships between the career stages and involvement in educational activities. The calculated coefficients allow to perform the comparisons of the degree of association. The largest association occurs in the case of formal education, and the lowest in the case of non-formal education.

As there are three learning forms in question, three-way contingency tables may be examined for detecting interactions among all variables. Log-linear models are applied for this purpose. The results of log-linear modeling are shown in Table 3.

Table 3. Best log-linear models for participation in various types of continuous education ( $F$ - formal education, $N$ - nonformal education, I - informal education)

\begin{tabular}{lccc}
\hline Stage & Log-linear model & Likelihood ratio chi-square & p-value \\
\hline Exploration & {$[\mathrm{FN}][\mathrm{FI}][\mathrm{NI}]$} & 0,765 & 0,382 \\
Establishment & {$[\mathrm{FNI}]$} & 0,000 & 1,000 \\
Maintenance & {$[\mathrm{FN}][\mathrm{FI}][\mathrm{NI}]$} & 0,007 & 0,935 \\
\hline
\end{tabular}

Source: Own computations based on data from Bilans kapitału ludzkiego 2013

Simplified models than saturated one are found for relationships of educational activities in case of the exploration and maintenance stages. The detected pattern is called homogeneous association meaning that no three-way interactions are present. The associations between any two forms of education do not depend on the third one. The third-order effect cannot be omitted in case of the establishment stage indicating that there are interactions among all forms of education.

The results of log-linear modeling in case of three variables are portrayed by three- dimensional mosaic plots in Figure 2. The volumes of the cuboids represent the contingency table cells frequencies corresponding to fitted values of log-linear models for exploration and maintenance categories. 
Figure 2. Three-dimensional plots corresponding to fitted values of log-linear models for Exploration (left) and Maintenance (right) : 0 - lack of participation, 1 - participation
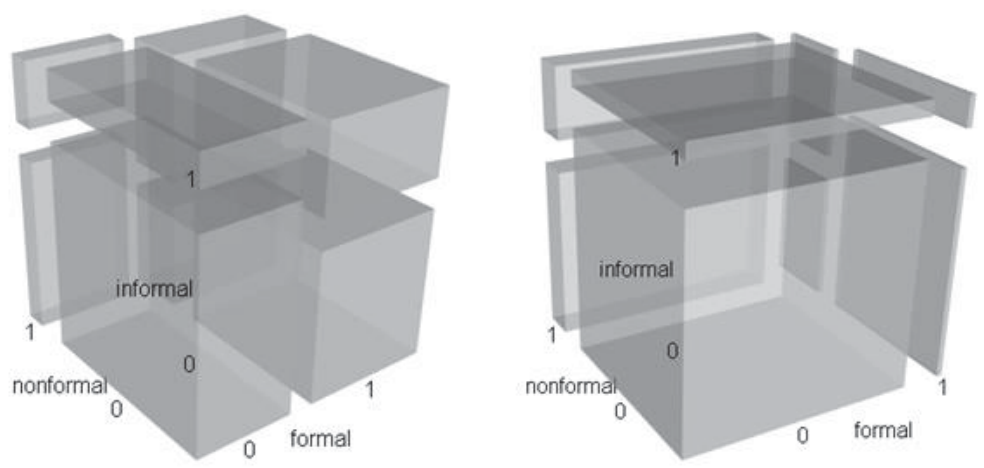

Source: Own elaboration in R based on data from Bilans kapitału ludzkiego 2013

As the goodness-of-fit of the models is good no meaningful discrepancies are indicated. It should be underlined that the participation in education patterns differ essentially between the youngest and the oldest part of the labour force. The case of the maintenance stage is dominated by one big cuboid reflecting the combination of lack of participation in all three lifelong learning activities. In case of the exploration stage the division is not so strongly dominated by a certain combination of educational behaviors.

\section{Career Stages and Attitude to Educational Activities}

As it was shown above the lowest participation rate in lifelong learning activities is observed at the end of the professional career path (maintenance stage). The question is whether the perception of the ability to learn new things differs essentially between respondents from various age groups and whether age itself is considered as a barrier to involvement in training.

Double-decker plots portraying the contingency tables for the age intervals and the evaluation of the ability to learn new things as well as the perception of age as a barrier to learning are shown in Figure 3.

Figure 3. Doubledecker plots showing relationships between the career stages and the attitudes to lifelong learning activities

age as barrier

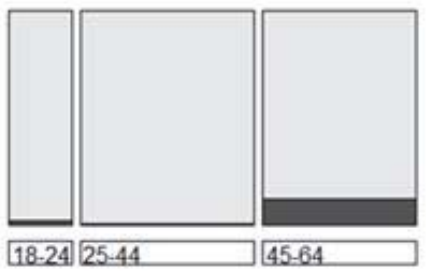

ability to learn new things

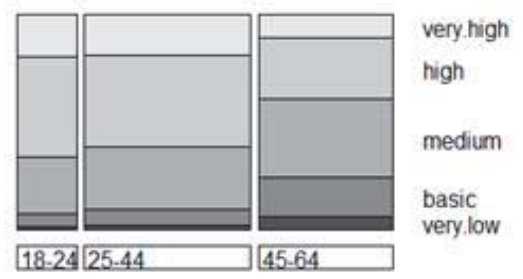

Source: own elaboration in R based on data from Bilans kapitału ludzkiego 2013

Persons being at the maintenance stage tend to perceive age as a barrier to undertake educational activities more frequently than the others. Moreover their self-esteem in terms of the ability to learn is lower than among persons at the exploration and establishment stages of career. These differences are also reflected in chi-square test results as well as contingency coefficients (Table 4). 
Table 4. Measures of association between the career stages and the attitude to lifelong learning process

\begin{tabular}{lcccc}
\hline Type & Chi-square statistic & $\mathbf{p}$-value & Contingency coefficient & Goodman Kruskal Tau \\
\hline Age as a barrier to education & 1200,519 & 0,000 & 0,253 & 0,017 \\
Ability to learn new things & 847,440 & 0,000 & 0,236 & 0,059 \\
\hline
\end{tabular}

Source: Own computations based on data from Bilans kapitału ludzkiego 2013

Chi-square test points out that there are significant relationships between the career stages and the considered factors. Low values of Goodman and Kruskal Tau measure indicate that there is a small reduction in error when predicting the attitudes from the knowledge of career stages.

The attitude to learning activities may be also evaluated by analyzing a metric variable representing number of years since the last participation in training. The task is to verify the hypothesis that the average time since the last participation is the same at all distinguished career stages. In order to check whether classical ANOVA may be applied, quantile-quantile plots (Figure 4) as well as Kolmogorov-Smirnov test of normality (Table 5) are used.

Figure 4. Quantile-Quantile plots for Number of years since the last participation in training according to three career stages
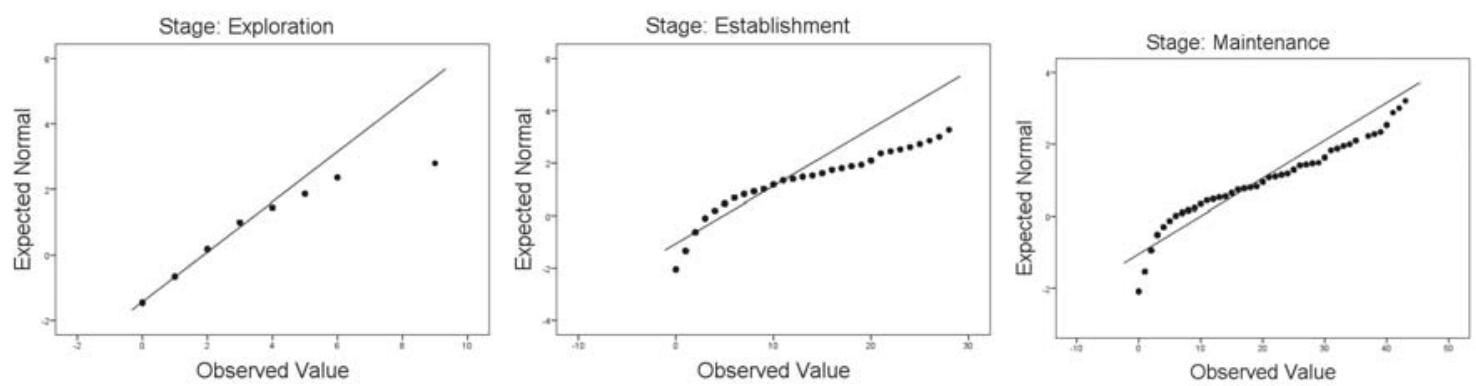

Source: Own elaboration based on data from Bilans kapitału ludzkiego 2013

Both plots and test results show that the assumption of normality is not held, so the use of the classical analysis of variance is not possible. The suggested solution is the Kruskal-Wallis non-parametric test. The null hypothesis is that the mean ranks of the variable in question are the same across all categories of career stages contrasted with the alternative hypothesis that it is not true at least in two samples. As Kruskal-Wallis statistics is equal to 558,540 with corresponding pvalue 0,000 the null hypothesis must be rejected. The time since the last training differs between the groups which are at different career stages.

Table 5. Test of normality: Number of years since the last participation in training

\begin{tabular}{lcc}
\hline Stage & Kolmogorov-Smirnov statistic & p-value \\
\hline Exploration & 0,241 & 0,000 \\
Establishment & 0,216 & 0,000 \\
Maintenance & 0,188 & 0,000 \\
\hline
\end{tabular}

Source: Own computations based on data from Bilans kapitału ludzkiego 2013

Pairwise comparisons are performed to evaluate the differences (Table 6). The differences are significant for every pair of career stages. 
Table 6. Pairwise comparisons: Number of years since the last participation in training

\begin{tabular}{lccc}
\hline Pairs & Test statistic & p-value & Adjusted p-value \\
\hline Exploration - Maintenance & $-22,336$ & 0,000 & 0,000 \\
Establishment - Maintenance & $-14,741$ & 0,000 & 0,000 \\
Exploration - Establishment & $-13,709$ & 0,000 & 0,000 \\
\hline
\end{tabular}

Source: Own computations based on data from Bilans kapitału ludzkiego 2013

\section{Time and Expenditure Spent on Training at Various Career Stages}

Other indicators characterizing the involvement in the skills development at different career stages are the expenses and the time spent on training. These variables are metric in nature, so either ANOVA or its Kruskal-Wallis analogy are adequate techniques for detecting possible differences.

Quantile-quantile plots (Figure 5) and Kolmogorov-Smirnov test of normality (Table 7) are applied to data concerning the total personal expenditure on training during the last 12 months.

Figure 5. Quantile-Quantile plots for Total personal expenditure on training according to three career stages
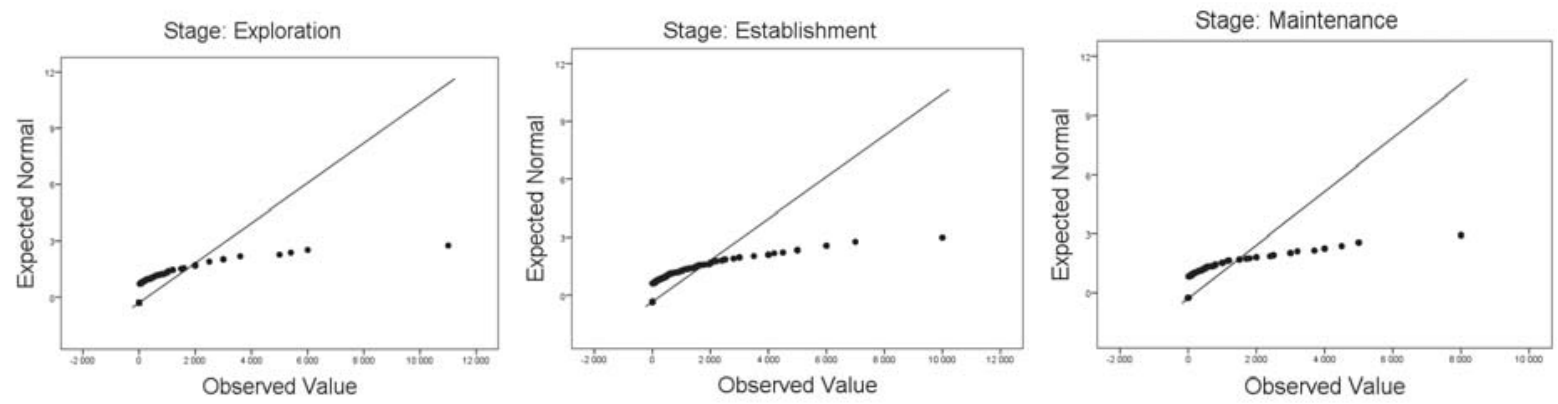

Source: Own elaboration based on data from Bilans kapitału ludzkiego 2013

Table 7. Test of normality: Total personal expenditure on training (last 12 months)

\begin{tabular}{lcc}
\hline Stage & Kolmogorov-Smirnov statistic & p-value \\
\hline Exploration & 0,385 & 0,000 \\
Establishment & 0,366 & 0,000 \\
Maintenance & 0,412 & 0,000 \\
\hline
\end{tabular}

Source: Own computations based on data from Bilans kapitału ludzkiego 2013

Both quantile-quantile plots and test results indicate that the distributions of the expenses are not normal, so there is no rationale for performing classical analysis of variance. Kruskal-Wallis test is used instead. Its statistic equal to 14,978 with corresponding p-value 0,001 suggests that the null hypothesis of the same distribution of expenses across the three categories should be rejected. The results of pairwise comparisons (Table 8) reveal that the distributions of the expenses differ substantially between establishment and maintenance stages.

Table 8. Pairwise comparisons: Total personal expenditure on training (last 12 months)

\begin{tabular}{lccc}
\hline Pairs & Test statistic & p-value & Adjusted p-value \\
\hline Exploration - Maintenance & 1,433 & 0,152 & 0,456 \\
Establishment - Maintenance & 3,830 & 0,000 & 0,000 \\
Exploration - Establishment & $-1,658$ & 0,097 & 0,292 \\
\hline
\end{tabular}

Source: Own computations based on data from Bilans kapitału ludzkiego 2013 
Normal distribution assumptions are also not met in the case of the variable representing the time devoted to training in the last twelve months (see Figure 6 and Table 9).

Figure 6. Quantile-Quantile plots for Number of hours devoted to training according to three career stages
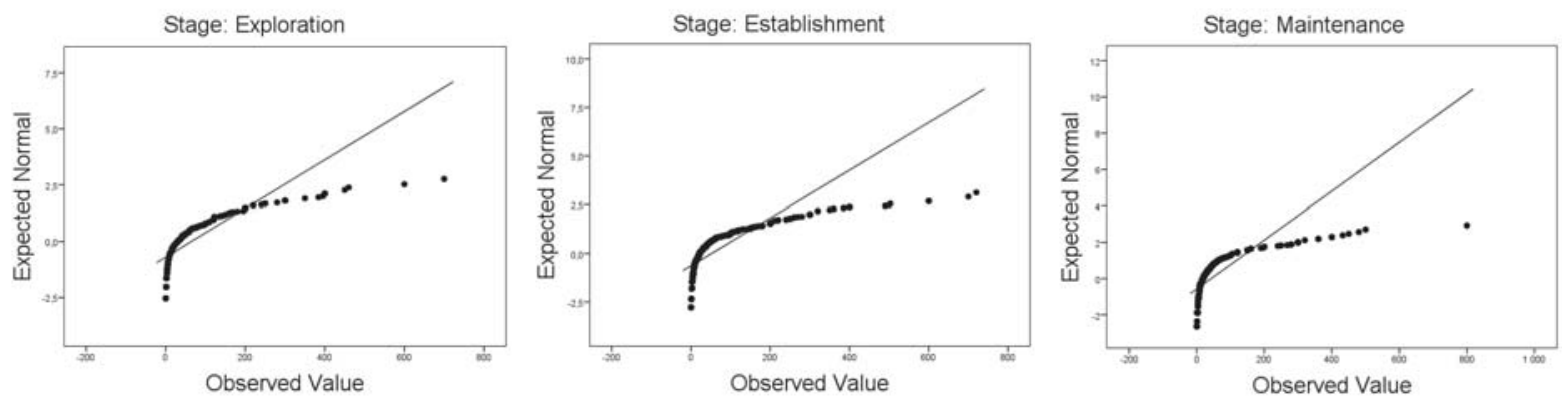

Source: Own elaboration based on data from Bilans kapitału ludzkiego 2013

Table 9. Test of normality: Number of hours devoted to training (last 12 months)

\begin{tabular}{lcc}
\hline Stage & Kolmogorov-Smirnov statistic & $\mathrm{p}$-value \\
\hline Exploration & 0,244 & 0,000 \\
Establishment & 0,263 & 0,000 \\
Maintenance & 0,285 & 0,000 \\
\hline
\end{tabular}

Source: Own computations based on data from Bilans kapitału ludzkiego 2013

Again, Kruskal-Wallis test based on ranks is applied to test the mean ranks of the number of hours spent on training. As the statistic is equal to 24,796 with corresponding $p$-value 0,000 null hypothesis is rejected meaning that the distribution of time is not the same across categories of career stages. Pairwise comparisons are given in Table 10.

Table 10. Pairwise comparisons: Number of hours devoted to training (last 12 months)

\begin{tabular}{lccc}
\hline Pairs & Test statistic & p-value & Adjusted p-value \\
\hline Exploration - Maintenance & 4,978 & 0,000 & 0,000 \\
Establishment - Maintenance & 2,473 & 0,013 & 0,040 \\
Exploration - Establishment & 3,416 & 0,001 & 0,002 \\
\hline
\end{tabular}

Source: Own computations based on data from Bilans kapitału ludzkiego 2013

Pairwise comparisons lead to the conclusion that the time spent on learning varies considerably between the exploration and maintenance phases and between exploration and establishment stages. The pattern of educational behavior for the younger group is different than for the others.

\section{Conclusions}

The attitudes to lifelong learning activities as well as developing skills process are different across persons being at the three career stages. The patterns of association vary with particular variables. Nevertheless, the hypothesis of the same attitudes at all career phases was rejected in any considered case.

\section{Acknowledgments}

This research was financed by Narodowe Centrum Nauki (National Science Centre) in Poland under the project entitled "Non-metric multivariate data analysis as a tool for study of adults situation in the context of demographic changes". 
Project number: 2012/05/B/HS4/02499.

The data on individuals were retrieved from the database Bilans Kapitału Ludzkiego - 2013 on 2015-01-03.

\section{References}

Christensen, R. (1997). Log-linear models and logistic regression. New York: Springer.

Czapiński, J. \& Panek, T. (eds. ). (2013). Social diagnosis 2013. Objective and subjective quality of life in Poland. Diagnoza Społeczna 2013. Warunki i Jakość Życia Polaków, Contemporary Economics, Vol. 7, pp. 1-491.

European Commission. (2006). Classification of learning activities - Manual. Luxembourg: Office for Official Publications of the European Communities.

European Commission. (2011a). Adults in Formal Education: Policies and Practice in Europe. Brussels.

European Commission. (2011b). Progress Towards the Common European Objectives in Education and Training. Indicators and benchmarks 2010/2011. Luxembourg: Publications Office of the European Union.

Everitt, B. S. (1992). The analysis of contingency tables. New York: Springer-Science+Business Media, B. V.

Friendly, M. (2000). Visualizing categorical data. Cary, NC: SAS Institute.

Friendly M. , Turner H. , Zeileis A. , Murdoch D. , Firth D. (2015). vcdExtra: vcd Extensions and Additions. R package.

Fischer, M. M. , \& Wang, J. (2011). Spatial data analysis: models, methods and techniques. Springer Science \& Business Media.

Grześkowiak, A. (2013). Statystyczna analiza aktywności edukacyjnej osób dorosłych w Polsce, Ekonometria, 2 (40), pp. 22-35.

Grześkowiak, A. (2014). Self-learning as a method of improving skills by adult Poles - evidence from non-metric survey data, [in: ] Proceedings of the 12th International Academic Conference, IISES, Prague, pp. 486-495.

Grześkowiak, A. (2015). Wielowymiarowa analiza uwarunkowań zaangażowania Polaków w kształcenie ustawiczne o charakterze pozaformalnym. Prace Naukowe Uniwersytetu Ekonomicznego we Wrocławiu (forthcoming).

GUS. (2009). Kształcenie dorosłych. Warszawa.

Hornik, K. , Zeileis, A. , \& Meyer, D. (2006). The strucplot framework: Visualizing multi-way contingency tables with vcd. Journal of Statistical Software, 17 (3), pp. 1-48.

Meyer, D. , Zeileis, A. \& Hornik, K. (2014). vcd: Visualizing Categorical Data. R package.

Reynolds, H. T. (1984). Analysis of nominal data. Beverly Hills and London: Sage Pubns.

Sheskin, D. J. (2003). Handbook of parametric and nonparametric statistical procedures. CRC Press.

Super, D. E. (1980). A life-span, life-space approach to career development. Journal of vocational behavior, 16 (3), pp. 282-298. 